\title{
A Comprehensive review on Dichrostachys cinerea
}

\author{
Swadhini Subramaniam $^{1 *}$ and Dhanalakshmi Jaganathan ${ }^{2}$ \\ Ph.D Research Scholar ${ }^{1}$, Assistant Professor ${ }^{2}$, Department of Biochemistry, \\ Bharathidasan College of Arts and Science, Ellispettai,Erode-638116.
}

\begin{abstract}
For a very long time, the medical plants have been used worldwide to treat human diseases and it serves as a safe source of drugs to cure several diseases and conditions through complementary medicine system. It is a native plant of Indian subcontinent, Africa and North Australia and is known to have significant pharmacological activities. The wide range of pharmacological activities of D.cinerea are due to the presence of different groups of active biological compounds present in it. Traditionally, D.cinerea has been used for the treatment the treatment of many diseases such as headache, toothache, dysentery, leprosy, coughs, syphilis and also as diuretic, anthelmintic, purgative and laxative. Research on the pharmacological, biological isolation of metabolites and biologically active compounds of this plant have already been done worldwide. However, the study to evaluate the complete therapeutic values of this plant still needed to conduct. This paper briefly reviews the various pharmacological properties of D.cinerea that could be useful for further experimental and clinical investigations.
\end{abstract}

Keywords : Dichrostachys cinerea, Pharmacological activities, therapeutic values

\section{Introduction}

Traditional medicine system remains the major source of health-care services worldwide [1,2]. Plants are the backbone of all the traditional medicinal practices used for the treatment of various health issues. Medicinal plants constitute a major growing part of modern high-tech medicine system. Rich heritage of medicinal plants are present in India with the availability of about 45,000 plants that are used in Ayurveda, Unani and Siddha medicine[3]. Dichrostachys cinerea is a potential medicinal plant that finds enormous uses as ethnomedicine[4,5]. Its bark is used for the treatment of headache, elephantiasis and dysentery. To treat coughs, syphilis, sore eyes and gonorrhea the root infusions are used. It is used as anthelmintic, strong diuretic and also as laxative[6].The leaves and bark of D.cinerea contain active drug compounds that are used for several ailments such as inflammations, toothache, fever, ulcers, wounds, chest problems, jaundice and rheumatism. It also possess aphrodisiac property[7,8]. In Orissa, the local tribes of Mayurbhanji use the bark of this plant for treating diabetes mellitus. In India, D.cinerea is also used as a veterinary medicine[9]. The root powder is used to massage for fractures. The leaves are used in the treatment of piles, eczema and arthritis[10].

In semi-arid areas in Kenya, Somalia and Eritrea D.cinerea is one of the useful wild medicinal plant[11]. The Mwaghal tribe in Mangu use D.cinerea as an effective antidiarrhoeal plant. The roots are used for bites or stings. In southern India, it is used as a Siddha medicine by the Tamil people for treating eczema, syphilis and gonorrhea[12]. In Ivory Coast traditional medicine, the stem bark of this plant is used for the treatment of airways infection[13,14]. The village people of Rayalaseema (Andhra Pradesh, India) use D.cinerea roots for treating renal troubles and urinary calculi[15,16].In Gabon, the bark of this plant is used to treat various pathologies[17]. This plant is used for the treatment of measles and dental caries. Its barks facilitate childbirth [18]. The plant extract was found to exhibit hepatoprotective activity[19]. The roots of this plant is reported as anodyne, astringent, febrifuge and are used against vaginitis[20,21,22,23]. Adioukrous peoples use D.cinerea root bark to treat asthma[24]. In Ayurveda, D.cinerea is used as yoniroga, trsna, mutraghata, asmari and sandhisula[25]. The plant extract is used by Maasai to treat 
malaria[26]. The plant is also used for treating leucorrhoea[27]. Bark and leaf extract of this plant is used to treat boils[28].

\section{Plant description:}

Dichrostachys cinerea is a perennial, thorny much branched shrub sometimes a fast growing semideciduous to deciduous tree belonging to the family Mimosaceae[29,30,31]. It is native to Africa, North Australia and also found in the dry shrub forest and arid hills of northwestern, central and southern India[32,33]. This plant is commonly known as sickle-bush, Bell mimosa, Chinese lantern tree or Kalahari Christmas tree[34]. The plant reaches 3-7 $\mathrm{m}$ in height and have alternate strong thorns that are up to $8 \mathrm{~cm}$ long[35,36,37]. The plant has a $3 \mathrm{~m}$ wide open round crown. The young bark is green in color and as the tree grows it becomes grey-brown and fissured. The diameter of the stem is less than $23 \mathrm{~cm}$ $[35,38]$. The leaves that grow up to $15 \mathrm{~cm}$ long are bipinnate, petiolated and have 4-19 leaflets. The flower is a fragrant, cylindrical bicolored spike resembling Chinese lanterns with 6 to $8 \mathrm{~cm}$ long, that bears sterile, lilac or pale-purple flowers in the upper part and fertile, pale yellow-cream flowers in the lower part[35,37]. The plant has a narrow fruit with $10 \mathrm{~cm}$ long, crowded, ondulate, glomerate, contorted, yellow or mustard brown color pods that are usually twisted or sickle shaped[34,36]. Four seeds present in the pod[35]. The plant has many lateral roots and a deep tap root[39]. D.cinerea. ssp. africana and D. cinerea ssp. nyassanaare the two recognized subspecies of this plant[34].

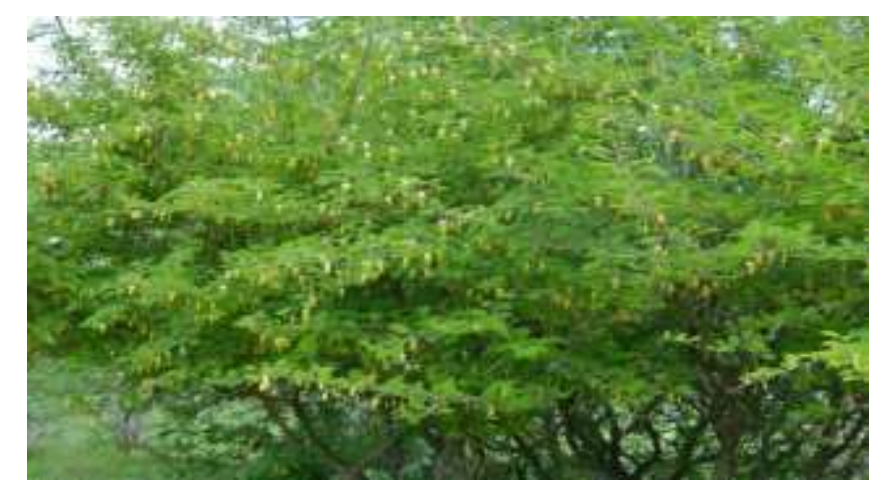

Figure 1: Dichrostachys cinerea- the whole plant

Table 1: Plant description

\begin{tabular}{|c|c|c|}
\hline Picture & Parts & Description \\
\hline
\end{tabular}




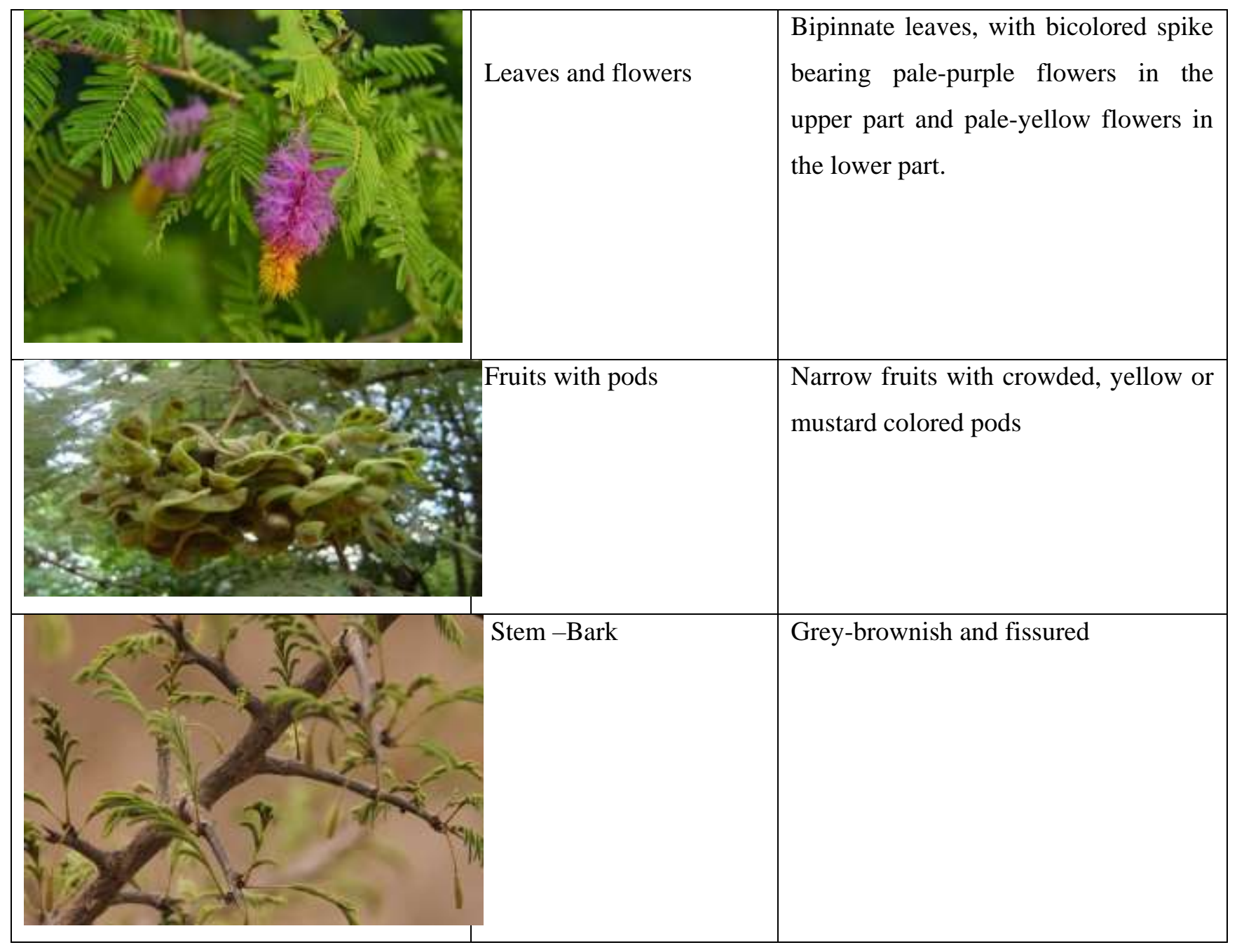

\section{Distribution:}

The species is native to Africa, North Australia and Indian subcontinent[33]. It is then spread to America, Southeast Asia and Carribean[40,41]. D.cinerea is also found in Nigeria, Zambia, Cameroon, Swaziland, Uganda and Ghana[34]. It is the common species of Nechisar National Park, Ethiopia[41]. The plant has also been found in Cuba and Peninsular Florida. The species grows in rainforest zones and it also occurs in thickets, hedges, teak forest, degraded lands, brushwood, frost-free areas, and grassland. In India, it is found in dry deciduous forest[40,34].

Taxonomical classification: [42]

Kingdom: Plantae

(unranked): Angiosperms

(unranked): Eudicots

(unranked): Rosids

Order: Fabales

Family: Fabaceae

Genus: Dichrostachys

Species: D. cinerea 
Synonym :[43]

- Caillieadichrostachys Guill. et al.,

- Caillieanutans (Pers.) Skeels,

- Dichrostachyscinerea subsp. lugardae (N. E. Br.) Brenan \&Brummitt,

- Dichrostachyscinerea var. hirtipes Brenan \&Brummitt,

- Dichrostachyscinerea var. lugardiae Brenan \&Brummitt,

- Dichrostachysforbesii Benth.,

- Dichrostachysglomerata (Forssk.) Chiov.,

- Dichrostachysnutans (Pers.) Benth.,

- Dichrostachysnutans var. setulosa Welw. exOliv.,

- Dichrostachysnyassana Taub.,

- Dichrostachysplatycarpa Welw. ex W. Bull,

- Mimosa cinerea L.,

- Mimosa glomerata Forssk.,

- Mimosa nutans Pers.

Common name: [44]

- English -Kalahari Christmas tree, Marabou-thorn, Sickle bush, Princess's Earrings, Painted Thorn Bush, chinese Latern tree

- Gujarati- Marud, Mordundiyun

○ Hin- Vurtuli

○ Hindi- $\square \square \square \square$ Khairi, $\square \square \square \square \square \square$ Veerataru, $\square \square \square \square \square \square$ Kunali

- Irula- Odavarai

- Kannada- VaduvaradaGida, Wadu, Odavinaha

- Malayalam- Vedathala, Vitattal, Vidatthal, Veeravriksham

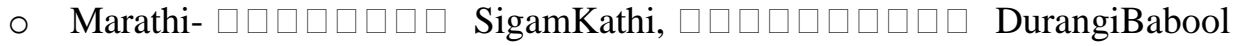

○ Oriya- Khoiridya

- Sanskrit- Viradru, Vellantaru

- Tamil- Vedathalaa, Veduttalam

○ Telugu- Nellajammi

Phyto constituents:

Various studies have revealed that ethanol, methanol, chloroform, petroleum ether, Hexane, Ethyl acetate, Acetone and aqueous extract of different parts of Dichrostachys cinerea contains various chemical groups such as Alkaloids, Flavonoids, Carbohydrates, Saponins, Tannins, Anthocyanin and Betacyanin, Coumarins, Steroids and Phytosteroids, Phenols, Aminoacids and proteins, Terpenes, Triterpenes, Diterpenes, aliphatics, Cardiac glycosides[45,46,47,48,49,50] and cardiotonicHeterosides[51]. An extensive phytochemical analysis of D.cinerea revealed the presence of $\beta$ - amyrin, $\beta$ - sitosterol, esculetin, imperatorin, marmesin[52,53] $\alpha$ - amyrin, stigmasterol[50],octasanol, friedelin-3-one[54], friedelin, friedelin 3 $\beta$-one[55] and 3-o-acyl mesquitol[56].

The flower showed the presence of quercetin. $\beta$ - amyrin acetate was also reported in another study conducted by Sreedevi Adikay et al., 2009[57]. Rao J.M et al., (2004), reported the presence of epicatechin[58]. Earlier studies reported the presence of apigenin, kaempferol, myricetin, apigenin-7-Oapiosyl $(1 \rightarrow 2)$ glucoside, myricetin-3- $O$-rhamnopyranoside, myricetin-3- $O$-glucopyranoside , quercetin-3$O$-rhamnopyranoside, quercetin-3- $O$-glucopyranoside ,chrysoeriol-7- $O$-apiosyl $(1 \rightarrow 2)$ glucoside andclovamide[59,60]. C. Long et al., reported the presence of meroterpenederivatives, dichrostachines A-R[61]. The table below summarizes the reported phytoconstituents in Dichrostachys cinerea [58-65]. 


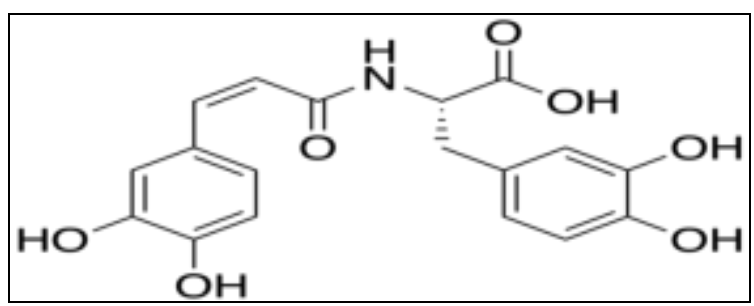

Figure-2: Clovamide

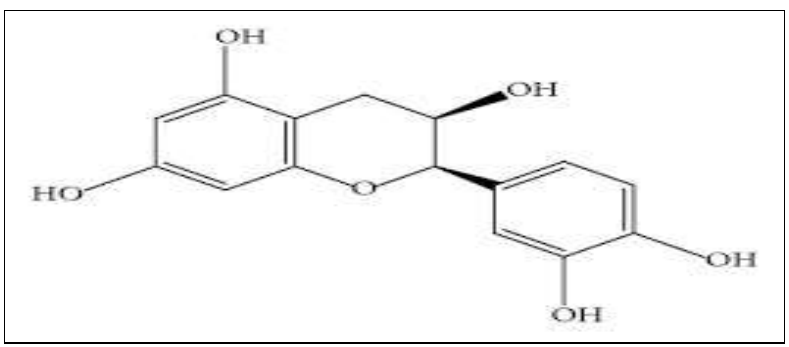

Figure-3: Epicatechin

Table 2: Reported phytoconstituents in Dichrostachys cinerea

\begin{tabular}{|ll|}
\hline compounds/ groups & plant part \\
\hline [ apigenin, kaempferol, myricetin & \\
apigenin-7- $O$-apiosyl $(1 \rightarrow 2)$ glucoside, & \\
myricetin-3- $O$-rhamnopyranoside, & \\
myricetin-3- $O$-glucopyranoside, & \\
quercetin-3- $O$-rhamnopyranoside, & Leaves \\
quercetin-3- $O$-glucopyranoside, & \\
chrysoeriol-7- $O$-apiosyl $(1 \rightarrow 2)$ glucoside & \\
andclovamide ] & \\
Dichrostachins A-R & Bark and Root \\
{$\left[\mathrm{C}_{30} \mathrm{H}_{50} \mathrm{O}\right.$} & Bark \\
$\mathrm{C}_{29} \mathrm{H}_{58} \mathrm{O}_{4}$ & \\
$\mathrm{C}_{15} \mathrm{H}_{10} \mathrm{O}_{4}$ & \\
$\mathrm{C}_{15} \mathrm{H}_{10} \mathrm{O}_{4}$ & \\
\hline
\end{tabular}

\section{Pharmacological activities:}

1. Hepatoprotective activity:

Several medicinal plants are used to treat degenerative fibrotic hepatic diseases caused by alcohol consumption[66]. A study conducted for 14days on albino mice and rats clearly indicated that the methanolic extract of D.cinerea leaves showed to have great hepatoprotective activity(ld50) against ccl4induced liver damage, in which the methanol extract did not show any mortality up to a dose of 3500 $\mathrm{mg} / \mathrm{kg}$ body weight[67]. 


\section{Anti-diabetic activity:}

An elaborate study was performed to determine the anti-hyperglycemic activity in various fractions of hydro-alcoholic extract of D.cinerea roots, treated on 12groups of Male Wistar rats. Among all the extracts, aqueous ethanolic and ethyl acetate extracts showed maximum anti-hyperglycemic activity at a dose of $400 \mathrm{mg} / \mathrm{kg}$ and the efficacy of these two extracts (ethyl acetate and hydro-alcoholic) were found to be greater than the hypoglycemic activity of glibenclamide $(10 \mathrm{mg} / \mathrm{kg})$ in the test rats[68].

\section{Broncho-relaxation activity:}

In order to determine the broncho-relaxation property of Dichrostachys cinerea, a study was carried out with the hydro-alcoholic extract of the plant's root sample in guinea-pig trachea preparations. The pre-contracted tracheal chain was found to be relaxed by the hydro-alcoholic root extract's (concentration up to $2 \mathrm{mg} / \mathrm{dl}$ ) active compounds. The plant possess this property by complying many facets such as by the opening effect of potassium channels, blocking calcium channels, acting via adrenergic receptors activation and/or by the antagonistic action on $\mathrm{H}_{1}$ - histaminergic receptors[69].

\section{Nephro-protective activity:}

Nephro-protective effect against cisplastin-induced renal injury in Wistar strain albino rats were studied in the alcoholic extract of Dichrostachys cinerea $\operatorname{root}(200$ and $400 \mathrm{mg} / \mathrm{kg})$. The alcoholic extract showed dose dependent protection in the curative regimen. The extract also showed better reducing property based on the dose and good nitric oxide scavenging activity even at lower concentration $(50 \mu \mathrm{g} / \mathrm{ml})[57]$.

\section{Antidiarrheal activity:}

A study was conducted to investigate the antidiarrheal activity of ethanolic extract of Dichrostachys cinerea stem-bark(EDCB), ethanolic extract of Dichrostachys cinerea leaf(EDCL) and ethanolic extract of Dichrostachys cinerea root(EDCR) by small intestinal transit model and castor oil induced model. The extracts used at two doses $(200 \mathrm{mg} / \mathrm{kg}$ and $400 \mathrm{mg} / \mathrm{kg})$ reduced wet faecal matter and number of defaecation when compared to control. The percentage inhibition of EDCR, EDCL and EDCB was found to be $66.02 \%, 72.41 \%$ and $46.87 \%$ respectively at the dose of $400 \mathrm{mg} / \mathrm{kg}$. Tannins present in the D.cinerea plant, may be responsible for the antidiarrhoel activity by forming protein tannate that cause an astringent action[70]. In another study, conducted to analyse the in vitro antibacterial activity of the petroleum ether, ethanol and aqueous extracts of Dichrostachys cinerea on some bacteria associated with diarrhoea revealed the plant's antidiarrhoeal activity in a dose depended manner[47].

\section{Anti-malarial activity:}

An in vitro and in vivo study was carried out to investigate the anti-malarial activity of dichloromethane(DCM) and methanol extracts of Commiphora africana (stem bark and whole stem)and Dichrostachys cinerea(stem bark and whole stem)against chloroquine resistant (Dd2) and chloroquine Balb/c mice sensitive (D6) strains of Plasmodium falciparum. Lactate dehydrogenase method (pLDH) was used to assess the anti-malarial property (in vitro) and Peter's 4-day suppressive test in Plasmodium bergheiin Balb/c mice was carried out for the in vivo anti-malarial study. In the in vitro anti-plasmodial study, DCM extract of D.cinerea whole stem and C.africana stem bark showed higher anti-plasmodial activity $\left(\mathrm{IC}_{50}=11.47 \pm 2.17 \mu \mathrm{g} / \mathrm{mL}\right.$ and $4.54 \pm 1.80 \mu \mathrm{g} / \mathrm{Ml}$ respectively) against D6 strain of P.falciparum and the DCM extract of D.cinerea stem bark showed good activity against both Dd2 and D6 strains of P.falciparum $\left(\mathrm{IC}_{50}=11.92 \pm 7.43 \mu \mathrm{g} / \mathrm{mL}\right.$ and $2.37 \pm 0.86 \mu \mathrm{g} / \mathrm{Ml}$ respectively $)$. In the in vivo mouse model, 
the DCM extracts of D.cinerea(stem bark) and C.africana(stem bark) equally showed significant antimalarial activity with the parasite suppression rates of $53.12 \%$ and $64.24 \%$ respectively[71].

\section{Antioxidant activity:}

A study investigating the anti-oxidant activity of D.cinerea bark different extracts (aqueous, ethyl acetate, butanol, dichloromethane and methanol) revealed a positive correlation between total phenolic levels and anti-radical activity, between total phenolics and antioxidant activity. Among all the extracts, dichloromethane and ethyl acetate extracts showed significant antioxidant activity with the higher value

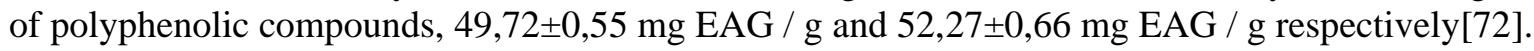

\section{Facilitate Childbirth:}

A study was conducted to analyse the childbirth facilitating property of the methanolic extract of D.cinerea bark on isolated uterine muscle from the pregnant rats and its effect was compared to the oxytocin generally used by the obstetricians to facilitate childbirth. Treatment of the isolated strips of the uteri of pregnant rats with methanol extract of D.cinerea of different concentrations $(3.2 \mu \mathrm{g} / \mathrm{ml}, 16 \mu \mathrm{g} / \mathrm{ml}$, $80 \mu \mathrm{g} / \mathrm{ml}, 400 \mu \mathrm{g} / \mathrm{ml}$, and $2 \mathrm{mg} / \mathrm{ml}$ )caused an increase in contractile force of the uterine fragments like that of oxytocin concentrations $\left(8.4 \times 10^{-5} \mu \mathrm{g} / \mathrm{ml}, 8.4 \times 10^{-4} \mu \mathrm{g} / \mathrm{ml}, 8.4 \times 10^{-3} \mu \mathrm{g} / \mathrm{ml}, 8.4 \times 10^{-2} \mu \mathrm{g} / \mathrm{ml}\right)$. The maximum contraction amplitude of D.cinerea and oxytocin was found to be $39.68 \mathrm{mN}$ at $400 \mu \mathrm{g} / \mathrm{ml}$ and $55.82 \mathrm{mN}$ at $8.4 \times 10^{-2} \mu \mathrm{g} / \mathrm{ml}$ respectively[73].

\section{Anti-proliferative activity:}

Water and methanolic extracts from four plant species namely D.cinerea, Aloe secundiflora, Vernonia zanzibarebsis and Maytenus obscura were investigated for the anti-proliferative activity by MTT assay, using cervical cancer cells (HeLa), prostate cancer cells (DU145 and 22Rv1) and African green monkey cells (Vero) cell lines. At the concentrations of $1.37 \mu \mathrm{g} / \mathrm{ml}$ to $1000 \mu \mathrm{g} / \mathrm{ml}$, all the extracts suppressed the growth of cancer cells in a dose-dependent manner. Among the plant extracts studied, D.cinerea stem bark methanol extract showed a low cytotoxic effect against the Vero cells with a CC50 of $812.1 \pm 12.72 \mu \mathrm{g} / \mathrm{ml}$ and the highest anti-proliferative activity with an $\mathrm{IC}_{50}$ of IC50 of $8.04 \pm 2.02$ $\mu \mathrm{g} / \mathrm{ml}$ against the $22 \mathrm{Rv} 1$ cells[74].

In another study, apoptosis in CCRF-CEM cells were induced by the crude extract of Dichrostachys cinerea bark, mediated mostly by increased production of Reactive Oxygen Species(ROS) and through alteration in Mitochondrial Membrane Potential (MMP).The isolated constituents Triterpenoid and flavone with an $\mathrm{IC}_{50}$ values below $50 \mu \mathrm{M}$ showed good cytotoxic effect against the 9 tested Multifactorial Drug-Resistant Cancer Cell lines. The recorded IC50 values varied from , $18.90 \mu \mathrm{M}$ (CCRF-CEM leukemia cells) to $88.86 \mu \mathrm{M}$ (against HCT116p53+/+ colon adenocarcinoma cells) for flavone, $7.65 \mu \mathrm{M}$ (towards multidrug-resistant CEM-ADR5000 leukemia cells) to $44.17 \mu \mathrm{M}$ (against HepG2 hepatocarcinoma cells) for triterpenoid and $0.02 \mu \mathrm{M}$ (against CCRF-CEM cells) to $122.96 \mu \mathrm{M}$ (against CEM/ADR5000 cells) for doxorubicin. Apoptosis was induced by the compound triterpenoid through MMP alteration, enhanced ROS production and through activation of the caspases[75].

\section{Analgesic and Anti-inflammatory activities:}

The chloroform extract of D.cinerea leaves $(15 \mathrm{mg} / \mathrm{kg}, 30 \mathrm{mg} / \mathrm{kg})$ showed a significant analgesic activity in the Swiss albino mice (acetic acid- induced writhing method). At a dose of $30 \mathrm{mg} / \mathrm{kg}$ body weight, the extract revealed a good reduction in the number of induced writhes when compared to standard aspirin given at a dose of $(100 \mathrm{mg} / \mathrm{kg})[76]$. An in vitro study was conducted to determine the analgesic and anti-inflammatory activity of the ethanolic extracts of D.cinerea's stem bark (EDCB), root 
(EDCR) and leaf (EDCL). Among all the extracts, EDCL showed good analgesic activity in centrally mediated analgesia (Eddy's hot plate method) and EDCR showed good analgesic activity in both centrally and peripherally mediated analgesia when compared to the standard carboxymethyl cellulose(Acetic acidinduced writhing method)[77] .

In a study conducted, chronic and acute model (cotton pellet granuloma and carrageenan-induced paw edema model, respectively) were used to investigate the anti-inflammatory activity of EDCL, EDCR and EDCB. Among the extracts studied( at a dose of $200 \mathrm{mg} / \mathrm{kg}$ and $400 \mathrm{mg} / \mathrm{kg}$ )EDCR showed a better reduction in granuloma formation at both doses (32.84\% and $33.84 \%$ respectively) and EDCL showed a significant reduction in volume of paw edema at both doses (63.64\% and $69.97 \%$ respectively)[77].

\section{Antimicrobial activity:}

Petroleum ether, ethanol and aqueous extracts of D.cinerea leaves showed antibacterial activity against Salmonella typhi, Escherchia coli and Shigella dysenteriae in a dose dependent manner[47]. The chloroform extract of the leaves was found to be active against the bacterial strains Pseudomonas, Vibrio cholera, Staphylococcus aureus, Bacillus brevis, Shigella flexneri and Salmonella typhi[76]. Aqueous and methanolic extracts of various D.cinerea explants possessed anti-bacterial activity against all the tested bacteria[78]. Tannins isolated from the ethanolic extract of the D.cinerea root exhibited significant antibacterial activity against the pathogens S.aureus, E.coli, Sh.fleneri, Sh.boydii and P.aeruginosa[49].

The effect of ethanol and aqueous extracts of D.cinerea stems and roots on the oral pathogens Staphylococcus saprophyticus, Candida albicansand Streptococcus mutans showed a significant inhibitory activity[79]. Ethyl acetate and methanol extracts of D.cinerea leaves showed a better antimicrobial activity against gram positive bacteria (S.aureus) than the gram negative bacteria (Sh.soneii)[80].

At a concentration of $20 \mu \mathrm{g} / \mu \mathrm{l}$, the isolated clovamide and the crude extract of the D.cinerea leaves exhibited a significant antiviral activity against influenza A virus (H5N1) infection (74\% and 73\% respectively). Clovamide showed a potential antitrypanosomal effect with an $\mathrm{IC}_{50}$ value of $3.27 \mu \mathrm{g} / \mathrm{ml}$ against Trypanosoma evansi when compared to the standard drug diminazene aceturate $\left(\mathrm{IC}_{50}=\right.$ $0.72 \mu \mathrm{g} / \mathrm{ml})[81]$.

\section{Toxicity:}

Varied lethal concentration potential was exhibited by the methanolic extracts of D.cinerea root, stem-bark and leaves through Brine shrimps test. Higher lethal effect was found in leaf than the root and stem-bark. At a concentration of $2000 \mathrm{ppm}$, the extracts showed $\leq 50 \%$ lethal effect and at concentrations above 2000ppm, had high lethal potential[78].

\section{Anti-venom activity:}

The methanol extract of Dichrostachys cinerea root $(200 \mathrm{mg} / \mathrm{kg})$ showed significant anti-venom activity against Russell's viper venom induced mice than the aqueous and ethereal extracts[82].

\section{Conclusion:}

Several studies on Dichrostachys cinerea have revealed its high medicinal Importance. It has been widely used as folk medicine or traditional medicine due to its different pharmacological properties. The plant extracts showed significant therapeutic activities including hepatoprotective, anti-diabetic, broncho-relaxation, nephro-protective, ant-diarrheal, anti-malarial, anti-oxidant, facilitate childbirth, antiproliferative, analgesic, anti-inflammatory, anti-microbial and toxicity properties. These activities may be 
due to the phytoconstituents present in various parts of the plant. Thus, further extensive studies needs to be done for its better use in pharmaceutical sector.

Acknowledgement:

The authors are grateful to Bharathidasan College of Arts and Science, Ellispettai, Erode-638116.

References:

1. Patel SS et al. Traditional medicine sources of new drugs, Pharma times, 2000, 34(1), 17-18.

2. Farooqi AA et al. Importance, present status and future prospects of medicinal crops. In recent progress in Indian medicinal plants, oxfort and IBH publishing co.pvt.Ltd, First edition, 2003,7,6972.

3. Hakim ZS, Santani DD, Gopal RK. Potential anti-diabetic agents from plant sources. J Nat Prod 1998;29:3-22.

4. Kerharo, J.; Adam, J. G. "La Pharmacope'eSe'ne'galaiseTraditionnelle, PlantesMe'dicinales et Toxiques"; VigotFre`res: Paris, 1974, pp. 573-575.

5. AbouZeid, A. H. S.; Hifnawy, M. S.; Mohamed, R. S. Planta Med., 2008, 74, 1020-1021.

6. Neondo JO, Mbithe CM, Njenga PK, Muthuri CW. Phytochemical characterization, antibacterial screening and toxicity evaluation of Dichrostachys cinerea. Int J Med Plant Res. 2012;1:32-37.

7. Igoli JO, Igwue IC, Igoli NP. Traditional medicinal practices among the Igede people of Nigeria. $J$ Herbs Spices Med Plants 2004;10:1049.

8. Bako SP, Bakfur MJ, John I, Bala EI. Ethnomedical and phytochemical profile of some savanna plant species in Nigeria. Int J Bot 2005;1:147-50.

9. Handal, J.T., Tooley, P. and Thompson, W. (2003). Survey of plants for antidiarrheal activities. Indian Journal of Applied Research,1(4): 223-236.

10. Swetha, Venna, C. and Poosa, I.R. (2013). Phytochemical and antimicrobial evaluation of Dichrostachys cinerea. International Research Journal of Pharmacy, 6(12):123-140.

11. Rukangira, E. (2004). Antibacterial activities of ethanolic extract of Dichrostacys cinerea on some pathogens and uses in the treatment of diseases. Indian Journal of Medicine and Plant Sciences, 2(4): 234-238.

12. Raamachandran, J. (2008). Herbs of Siddha Medicine/The First 3D Book On Herbs. Chennai: MuruganPatthipagam. pp. 76-. ISBN 978-8190612302.

13. Adjanohoun EJ, Aké-Assi L: Contribution au recensement des plantesmédicinales de Côte d'Ivoire. Collection médecinetraditionnelleetpharmacopée. Centre Nat Florist Univ Abidjan 1979, 358. 
14. Ouattara D: Recensementd'espècesvégétalesemployéesdans le traitement de l'Asthmebronchique: cas du District d'Abidjan (Côte d'Ivoire). Mémoire de maîtrise de botaniqueet de phytothérapieUniversitéd'Abobo-Adjamé; 2007, 34.

15. Thammanna and NarayanaRao, Medicinal Plants of Tirumala, Sri Prasad VS, E.O., T.T.D., Tirupati, 1990, p.36.

16. Vedavathy S, Mrudula V and Sudhakar A, Tribal Medicine of Chittoor District, A.P., India, Herbal folklore-Research Center, Tirupati,1997, p.86.

17. Walker A, Sillans R. Les Plantesutiles du Gabon, 1995. p 241 chap. 9.

18. AworetSamseny RRR. AbougheAngone S, KoumbaMadingou N, BoukandouMounanga M, Yao Datté J. Study of pharmacological properties of the methanolic extract of Dichrostachys cinerea bark (L.) Wight etArn (Leguminosae) in isolated myometrium frompregnant rats. Journal of Ethnopharmacology. 2015. Volume 169,1 Pages 195-199.

19. Babu PS, Krishna V, Maruthi KR, Shankarmurthy K, Babu RK. Evaluation of acute toxicity and hepatoprotective activity of the methanolic extract of Dichrostachys cinerea(Wight and Arn.) leaves. Pharmacognosy Research. 2011, Jan; 3(1):40.

20. Vaidyaratnam PS. "Indian Medicinal Plants. A Compendium of 500 Species", Vol-I, Orient Longman Ltd, Chennai, India; 1998; pp. 330-331

21. Zheng W, Wang SY, J. Agric. Food Chem., 2001, 49(11): 5165-5170.

22. Cai YZ, Sun M, Corke H., J. Agric Food Chem., 2003, 51(8): 2288-2294.

23. Kirthikar KR and Basu B.D. Indian Medicinal Plants. Publications and Information Division, vol II, CSIR, New Delhi, India; 1975; pp. 912-913.

24. E. J. Adjanohoun, L. Ake-Assi. Contribution au recensement des plantesmedicinales de Côte d'Ivoire Centre national de floristique Abidjan, CRESS, Abidjan, 1979.

25. Reviews on Indian Medicinal Plants. New Delhi: Published by Medicinal Plants Unit, Indian Council of Medicinal Research;2009. p. 9.

26. Nondo RSO, Zofou D, Moshi MJ, Erasto P, Wanji S, Ngemenya MN, et al. Ethnobotanical survey and in vitro antiplasmodial activity of medicinal plants used to treat malaria in Kagera and Lindi regions, Tanzania. J Med Plants Res. 2015;9:179-92.

27. Yoganarasimhan, SN. Medicinal plants of India, Regional Research Institute (Ayurveda); Bangalore, India: 2000.191

28. Orwa C, Jamnadass RH, Kindt R, Mutua A, Simons A (2009) Agroforestry database: A tree reference and selection guide version 4.0. [http://www.worldagroforestry.org/af/treedb/]. Accessed on: 15September 2018. 
29. Varier's P.S, Indian Medicinal Plants", Compendium of 500 species, AryaVaidyaSala, Kottakkal, Vol-2, 330-333, 1993.

30. Kirithikar K.R and Basu B.D, Indian Medicinal Plant, 2nd edn, Allahabad, India, Vol-2, 912-13, 1987.

31. Zeid AH, Hifnawy MS, Mohammed RS. Phenolic Compounds and Biological Activities of Dichrostachys cinerea L. Med Aromat Plant Sci Biotechnol. 2009; 3:42-49.

32. Kirtikar KR, Basu BD. Indian Medicinal Plants. Vol. 2. Dehradun: Bishan Singh Mahendra Pal Singh; 1984. p. 912-3.

33. Duthie, John Firminger (1973). https://archive.org/details/floraofupp11219031905duthFlora of the Upper Gangetic Plain and of the Adjacent Siwalik and Sub-Himalayan Tracts. Calcutta: Govt Printer India.

34. "World

Agroforestry

Centre". https://web.archive.org/web/20110930042837/http://www.worldagroforestrycentre.org/sea/products/ afdbases/af/asp/SpeciesInfo.asp?SpID=675Archived from the original on 2011-09-30. Retrieved 2008-06-22.

35. Orwa, C.; Mutua, A.; Kindt, R.; Jamnadass, R.; Anthony, S., 2009. Agroforestree Database: a tree reference and selection guide version 4.0. World Agroforestry Centre, Kenya

36. Göhl, B., 1982. Les aliments du bétail sous les tropiques. FAO, Division de Production et Santé Animale, Roma, Italy

37. "Dichrostachyscinerea Sickle Bush".http://home.intekom.com/ecotravel/plantkingdom/trees/dichrostachys-cinerea-sicklebush.htm Guide to the tree species of Southern Africa. Eco Travel Africa. n.d. Retrieved 27 August 2018.

38. SANBI, 2011. Dichrostachyscinerea. South African National Biodiversity Institute, South Africa

39. US Forest Service, 2011. Dichrostachys cinerea (L.) R. Wight \&Arnott. Pacific Island Ecosystems at Risk (PIER)

40. FAO, 2011. Grassland Index. A searchable catalogue of grass and forage legumes. FAO, Rome, Italy

41. "Nechisar National

Park".https://web.archive.org/web/20080609040218/http://realethiopia.com/nature/nationalparks/nechisar-national-park.html Archived from the original on 2008-06-09. Retrieved 2008-06-22. 42. "https://en.wikipedia.org/w/index.php?title=Dichrostachys_cinerea\&oldid=1028747552" 43. https://www.feedipedia.org/node/298 Last updated on October 7, 2015, 10:29 


\section{4. https://indiabiodiversity.org/biodiv/species/show/229560}

45. A Lavanya, V Ambikapathy. Preliminary qualitative analysis of phytoconstituents of Dichrostachys cinerea L. Journal of Pharmacognosy and Phytochemistry 2016; 5(3): 86-88.

46. Anita A. and Malar Retna A. A study on the bioactive compounds present in leaves of Dichrostachys cinerea. Green Chemistry \& Technology Letters, 2016; 2(1): 20-25.

47. Zumbes, H.J; Mawak,J.D; Babalola, O.B; Chinyelu, C; Ekpiwre, D.V; Gokir, J.D; Dabo, A.D. Antibacterial and Antidiarrhoeal Activities of Dichrostachys cinerea against some enteric pathogens. International Journal of Scientific Research. 2015; 4(11):412-415.

48. A. G. Irié-N'guessan. Rôle des ions potassium et de l'épithéliumdans la relaxation du muscle lissetrachéal : application à la propriétéantispasmodique de cinqplantesantiasthmatiques issues de la pharmacopéeivoirienne, Thèse de Doctorat en Sciences Pharmaceutiques, Université Félix Houphouët-Boigny, 193 pages, 2013.

49. Banso A, Adeyemo SO. Evaluation of antibacterial propertiesof tannins isolated from Dichrostachys cinerea. Afr J Biotechnol2007;6:1785-7.

50. Jain R, Saxena U. Aliphatics and triterpenoid's from theheartwood of Dichrostachys cinerea. $J$ Indian ChemSoc2003;80:656-8.

51. Tillement JP, Albengres E. Pharmacological approach to the rational use of cardiotonic heterosides. Coeur Med Interne. 1977; 16:239- 248.

52. Ernst WH, Kuites AT, Nelissen HJ, Tolsma DJ. Seasonal variation in phenolics in several savanas tree species in Botswana. Acta Bot Neeri 1991;40:63-24.

53. Harinder PS, Beckar K. Isolation of tannins from leaves of some tree and shrubs and their properties. Agric Food Chem 1994;42:731-4.

54. Krishna J, Sharma T. Chemical constituents of the root of Dichrostachys cinerea Macb and the stem bark and heart wood of Acacia leucophloea Willd. J. Indian Chem Soc 1977;54:649.

55. Krishna J, Sharma T. Triterpenoids and some other constituents from Dichrostachys cinerea. Phytochemistry 1974;13:2010-1.

56. JagadeeshwarRao R, Tiwari AK, Kumar US, Reddy SV, Ali AZ, Rao JM, et al. Novel 3-O-acyl mesquitol analogues as free-radical scavengers and enzyme inhibitors: Synthesis, biological evaluation and structure-activity relationship. Bioorg Med ChemLett 2003;13:2777-80.

57. Sreedevi Adikay, Bharathi Koganti and KVSRG Prasad, Effect of alcoholic extract of roots of Dichrostachys cinerea Wight \&Arn. Against cisplatin-induced nephrotoxicity in rats. Natural Product Radiance, 2009; 8(1): 12-18. 
58. Rao J.M, Yadav J.S, Raghavan K.V, Rao J.R, Tiwari A.K, "Antioxidant form natural scource", http://www. Pattentstorm. Us/patents/6781002 description, html, 2004.

59. R. T. El-Sharawy, A. Elkhateeb, M. M. Marzouk, R. R. AbdEl-Latif, S. E. Abdelrazig, and M. A. ElAnsari, "Antiviral andantiparasitic activities of clovamide: the major constituent of Dichrostachys cinerea (L.) wight et arn,” Journal of Applied Pharmaceutical Science, vol. 7, no. 9, pp. 219-223, 2017.

60. M. Vijayalakshmi, K. Periyanayagam, K. Kavitha, and K.Akilandeshwari, "Phytochemical analysis of ethanolic extract of Dichrostachys Cinerea W and Arn leaves by a thin layer chromatography, high performance thin layer chromatograph and column chromatography," Ancient Science of Life, vol. 32,no. 4, pp. 227-233, 2013.

61. C. Long, L. Marcourt, R. Raux et al., "Meroterpenes from Dichrostachys cinereainhibit protein farnesyltransferase activity," Journal of Natural Products, vol. 72, no. 10, pp. 1804-1815, 2009.

62. S. B.Mahato and A. P. Kundu, "13CNMRSpectra of pentacyclic triterpenoids - a compilation and some salient features," Phytochemistry, vol. 37, no. 6, pp. 1517-1575,1994.

63. R. N. Mbouangouere, P. Tane, D. Ngamga, P. Djemgou, M.I. Choudhary, and B. T. Ngadjui, "Piptaderol from Piptadenia africana," African Journal of Traditional, Complementary and Alternative Medicines, vol. 4, no. 3, pp. 294-298, 2007.

64. A.O. Oladimeji, I. A. Oladosu, M. S. Ali, and Z. Ahmed, "Flavonoids from the roots of Diocleareflexa(Hook F.)," Bulletin of the Chemical Society of Ethiopia, vol. 29, no. 3, pp. 441-448, 2015.

65. H. Yoon, S. Eom, J. Hyun et al., " $1 \mathrm{H}$ and 13C NMR data on hydroxy/methoxy flavonoids and the effects of substituents on chemical shifts," Bulletin of the Korean Chemical Society, vol. 32, no. 6, pp. 2101-2104, 2011.

66. Ram VJ: Herbal preparations as a source of hepato-protective agents. Drug News Perspect 2001; 14 : 353.

67. Babu PS, Krishna V, Maruthi KR, Shankarmurthy K, Babu RK. Evaluation of acute toxicity and hepatoprotective activity of the methanolic extract of Dichrostachys cinerea(Wight and Arn.) leaves. Phcog Res 2011;3:40-3.

68. Bolleddu R, Venkatesh S, Hazra K, Rao MM, Shyamsunder R. Anatomical and antihyperglycemic activity of Dichrostachyscinerearoots. Med J DY PatilVidyapeeth 2020;13:258-63.

69. Raissa RR Aworet-Samseny, Alain Souza, FideleKpahé, KiessounKonaté and Jacques Y Datté *BMC Complementary and Alternative Medicine 2011, 11:23

http://www.biomedcentral.com/1472-6882/11/23 
70. S.Jayakumari ,G.H.SrinivasaRao, J. Anbu, V.Ravichandiran. Antidiarrhoeal activity of Dichrostchys cinerea (L.) Wight \&Arn. Internal Journal of Pharmacy and Pharmaceutical sciences, vol 3, suppl 3, 2011, 61-63.

71. Prisca A. Kweyamba, Denis Zofou, NoellaEfange, Jules-Clement N. Assob, JovinKitau and MrambaNyindo. Malaria Journal (2019) 18:119

72. ReineRaissaRolandeAworetSamsey, Line-EdwigeMengome, Sophie AbougheAngone.Journal of complementary and Alternative Medical Research. 2020. Volume 11, Issue 3, page 1-11.

73. AworetSamseny RRR. AbougheAngone S, KoumbaMadingou N, BoukandouMounanga M, Yao Datté J. Study of pharmacological properties of the methanolic extract of Dichrostachys cinerea bark (L.) Wight etArn (Leguminosae) in isolated myometrium from pregnant rats. Journal of Ethnopharmacology. 2015. Volume 169,1 Pages 195-199.

74. Kimani PM, Mwitari PG, Njagi SM, Kirira PG, Kiboi DM (2018) In Vitro Anti-Proliferative Activity of Selected Plant Extracts Against Cervical and Prostate Cancer Cell Lines. J Cancer SciTher 10: 267-271

75. Armelle T. Mbaveng, Francois Damen, James D. SimoMpetga,Maurice D. Awouafack, Pierre Tane ,Victor Kuete and Thomas Efferth.Hindawi.Evidence-Based Complementary and Alternative Medicine .Volume 2019, Article ID 8450158, 11 pages.https://doi.org/10.1155/2019/8450158

76. U.S Mishra , S.R. Behera , P.N. Murthy, Manish Kumar and D.KumarInternational journal of Pharmacy and Pharmaceutical Sciences, vol. 1, Issue 2, Oct-dec.2009

77. E. Susithra, S. Jayakumari .Analgesic and anti-inflammatory activities of Dichrostachys cinerea (L.) Wight and Arn.Drug Invention Today | Vol 10 • Issue 3 • 2018 pages 361-366.

78. JohnstoneOmukhuluNeondo, Cecilia MweuMbithe, Peter KariukiNjenga and Catherine Wangari Muthuri. International Journal of Medicinal Plant Research Vol. 1 (4), pp. 032-037, September, 2012.

79. AdelodunL.Kolapo, MudashiruB.Okunade, Jacob A. Adejumobi and Mathew O. Ogundiya. In vitro Antimicrobial activity and Phytochemical composition of Dichrostachys cinerea. Medicinal and Aromatic Plant Science and Biotechnology. 2(2), 131-133. 2008.

80. Swetha Vennapoosa, DevareddySandeep, K.Sumathi, N.Senthil Kumar. Phytochemical and Antimicrobial evaluations of Dichrostachys cinerea. International Research Journal of Pharmacy. 2013, 4(1), 106-111.

81. El-Sharawy RT, Elkhateeb A, Marzouk MM, Abd El-Latif RR, Abdelrazig SE, El-Ansari MA. Antiviral and antiparasitic activities of clovamide: the major constituent of Dichrostachys cinerea $(\mathrm{L}$. Wight etArn. J App Pharm Sci, 2017; 7 (09): 219-223. 
82. H. B. Mishal / Journal of Natural Remedies, Vol. 2/1 (2002) 93 - 95 Screening of anti-snake venom activity of Dichrostachys cinereaW. \&A. 